\title{
Survival rate at middle age in developing and western populations
}

\author{
AleXANDER R. P. WALKer \\ D.Sc.

\begin{abstract}
South African Medical Research Council Human Biochemistry Research Unit, South African Institute for Medical Research, Johannesburg, South Africa
\end{abstract}

\begin{abstract}
Summary
Whereas expectation of life at birth invariably is greater in more privileged populations, the respective survival patterns at middle age can be entirely different. Comparisons have been made between South African and other populations, using, as a survival index, the number who are 70 years or more at present, as a percentage of the number who were 50 years or more 19 years earlier (data for the desired 20-year period were not available for all populations). Briefly (1) South African Negroes had the highest index; Indians both in India and South Africa the lowest; Caucasian populations in South Africa, United States, and England and Wales, were intermediate. (2) Indices for females were higher than for males; the disparity was least in Indians, but greatest for the population of England and Wales. Evidently, with progressive sophistication of diet and manner of life, the concomitant change from infections to degenerative diseases, as main causes of death at middle age and beyond, reduces rather than increases chances of survival.
\end{abstract}

\section{Introduction}

In primitive and developing populations, it is well known that expectation of life at birth invariably is lower than that in prosperous western or westernized populations. Little enquiry, however, has been pursued into the expectation of life in contrasting populations at middle age. In South Africa, census data have revealed that very old people, centenarians, when reckoned as a percentage of the total population, are more numerous among Negroes than Caucasians (Population Census, 1958 and 1963). This somewhat unexpected finding prompted enquiry into the age structure of the middle-aged and elderly segments of populations in South Africa (Negroes, Indians and Caucasians), as well as populations in some other countries. These were, (1) United States of America, to afford a comparison between American and South African Negroes (although the two populations did not derive from

Correspondence: Dr A. R. P. Walker, South African Institute for Medical Research, P.O. Box 1038, Johannesburg, South Africa. the same part of Africa); (2) India, to permit comparison between Indians in India and in South Africa, and (3) England and Wales, to allow a comparison to be made between British and South African Caucasians, since a large proportion of the latter derived from Britain.

Unfortunately, while information on expectation of life at middle age is available for many western populations, this is not the case with primitive or developing populations. It was therefore thought that an alternative approach would be to consider in each population the segments, male and female, that were 50 or more years of age in 1950-1951, and to calculate the respective percentages of survivors who were 70 years or over in a period 19 years later, in 1969-1970. Unfortunately, data for 20-year intervals for all populations under discussion were not available. This approach has therefore been pursued.

\section{Material and methods}

In South Africa, there are roughly 16 million Negroes, 4 million Caucasians, and $2 / 3$ million Indians. The forbears of the latter emigrated to South Africa two to three generations ago from India, chiefly from areas around Bombay and Madras.

Sources of data on age structure were: South Africa: Population Census (1958 and 1963); Statistical News Release (1972). India: Demographic Year Book (1971). England and Wales: Registrar General's Statistical Review (1953, 1972). United States: Statistical Abstract of the United States (1960); New Information Please Almanack (1972).

To provide additional perspective to findings, comparative data are needed on the wastage of life from 0 to 50 years in the three South African populations. This requires information on births at about 1900, and of deaths from 1900 onwards. Reliable inter-racial data, unfortunately, are not available. For example, in centres of population, accurate information on deaths, although not births, of Negroes is available, but only from 1936. To obtain a very rough appreciation of the situation. 
TABLE 1. Numbers of persons of 50 or more years, and of 70 or more years in 1951 and 1970

\begin{tabular}{|c|c|c|c|c|c|c|}
\hline \multirow{2}{*}{ Populations } & \multicolumn{3}{|c|}{1951} & \multicolumn{3}{|c|}{1970} \\
\hline & Male & Female & Total & Male & Female & Total \\
\hline \multicolumn{7}{|l|}{ Negroes } \\
\hline \multicolumn{7}{|c|}{ South Africa } \\
\hline $50+$ & 441,871 & 484,886 & 926,757 & 767,980 & 880,980 & $1,648,960$ \\
\hline $70+$ & 91,623 & 111,539 & 203,162 & 153,620 & 212,470 & 366,090 \\
\hline \multicolumn{7}{|l|}{ U.S.A.* } \\
\hline $50+$ & $1,296,758$ & $1,282,098$ & $2,578,856$ & $1,760,000$ & $2,142,000$ & $3,902,000$ \\
\hline $70+$ & 235,091 & 243,409 & 478,500 & 380,000 & 520,000 & 900,000 \\
\hline \multicolumn{7}{|l|}{ Indians } \\
\hline \multicolumn{7}{|c|}{ South Africa } \\
\hline $50+$ & $\begin{array}{r}16,774 \\
2999\end{array}$ & 9,996 & $\begin{array}{r}26,770 \\
4,403\end{array}$ & $\begin{array}{r}27,650 \\
2,990\end{array}$ & $\begin{array}{r}24,280 \\
2,780\end{array}$ & $\begin{array}{r}51,930 \\
5770\end{array}$ \\
\hline \multicolumn{7}{|l|}{ India } \\
\hline $50+$ & $21,994,100$ & $21,120,100$ & $43,114,200$ & $32,382,000$ & $29,432,000$ & $61,814,000$ \\
\hline $70+$ & $3,851,200$ & $4,016,600$ & $7,867,800$ & $4,574,000$ & $4,785,000$ & $9,359,000$ \\
\hline \multicolumn{7}{|l|}{ Caucasians } \\
\hline \multicolumn{7}{|c|}{ South Africa } \\
\hline $50+$ & 226,398 & 244,136 & 470,534 & 339,460 & 397,610 & 737,070 \\
\hline $70+$ & 50,726 & 54,670 & 105,396 & 59,960 & 94,000 & 153,960 \\
\hline \multicolumn{7}{|l|}{ U.S.A.* } \\
\hline $50+$ & $15,295,948$ & $15,960,716$ & $31,257,464$ & $20,256,000$ & $24,147,000$ & $44,403,000$ \\
\hline $70+$ & $3,137,322$ & $3,650,779$ & $6,788,101$ & $4,785,000$ & $6,918,000$ & $11,703,000$ \\
\hline \multicolumn{7}{|c|}{ England and Wales } \\
\hline $50+$ & $5,341,000$ & $6,883,000$ & $12,224,000$ & $6,571,600$ & $8,458,500$ & $15,030,100$ \\
\hline $70+$ & $1,189,000$ & $1,803,000$ & $2,992,000$ & $1,377,900$ & $2,615,800$ & $3,993,700$ \\
\hline
\end{tabular}

* Data on U.S.A. populations relate to the period 1950-1969.

TABle 2. Percentages of persons of 70 or more years, of those of 50 or more years

\begin{tabular}{|c|c|c|c|}
\hline Population & Male & Female & Total \\
\hline \multicolumn{4}{|l|}{ Negroes } \\
\hline South Africa & $34 \cdot 7$ & $43 \cdot 8$ & $39 \cdot 5$ \\
\hline U.S.A.* & $29 \cdot 3$ & $40 \cdot 5$ & $34 \cdot 8$ \\
\hline \multicolumn{4}{|l|}{ Indians } \\
\hline South Africa & $17 \cdot 8$ & $27 \cdot 8$ & $21 \cdot 6$ \\
\hline India & $20 \cdot 7$ & $22 \cdot 6$ & $21 \cdot 7$ \\
\hline \multicolumn{4}{|l|}{ Caucasians } \\
\hline South Africa & $26 \cdot 4$ & $38 \cdot 5$ & $32 \cdot 7$ \\
\hline U.S.A.* & $31 \cdot 2$ & $43 \cdot 3$ & $37 \cdot 4$ \\
\hline England and Wales & $25 \cdot 8$ & $38 \cdot 0$ & $32 \cdot 7$ \\
\hline
\end{tabular}

* Data on U.S.A. populations relate to the period 1950-1969.

some figures were obtained by means of questionnaires. These were filled in by series of 100 men and 100 women, aged 65-74 years, in average circumstances, in each ethnic group; they provided information on the numbers of brothers and sisters who were living or dead. Our calculations indicated that of persons born around 1900 , the approximate percentages who were still living in 1950, were, Negroes, $73 \%$, Indians, $79 \%$, and Caucasians, $83 \%$.

These figures concern particular segments and are not applicable to total populations.

\section{Results}

Results are summarized in the Tables 1-3.

\section{Comments of results}

Total populations. For the period studied, the highest survivor percentage was that of South
African Negroes, $39 \cdot 5 \%$. That for U.S.A. Negroes was $34.8 \%$. The values for Indians, in India, $21.7 \%$ and South Africa, $21.6 \%$, were very much lowe than those of the Negroes. The percentages for Caucasians were, in South Africa, 32.7\%, England and Wales, $32 \cdot 7 \%$ and U.S.A., $37 \cdot 4 \%$.

Sex differences. Percentages for males were invariably lower than for females. The disparity was least for Indians in India, but highest for the populations of England and Wales. Concerning

TABLE 3. Sex ratios of populations of 50 or more years, and of 70 or more years, in 1951 and 1970

\begin{tabular}{|c|c|c|c|}
\hline Population & & 1951 & 1970 \\
\hline \multicolumn{4}{|l|}{ Negroes } \\
\hline \multirow[t]{2}{*}{ South Africa } & $50+$ & $1: 1 \cdot 10$ & $1: 1 \cdot 15$ \\
\hline & $70+$ & $1: 1 \cdot 22$ & $1: 1 \cdot 38$ \\
\hline \multirow[t]{2}{*}{ U.S.A.* } & $50+$ & $1: 0.99$ & $1: 1 \cdot 22$ \\
\hline & $70+$ & $1: 1 \cdot 04$ & $1: 1 \cdot 37$ \\
\hline \multicolumn{4}{|l|}{ Indians } \\
\hline \multirow[t]{2}{*}{ South Africa } & $50+$ & $1: 0 \cdot 60$ & $1: 0.88$ \\
\hline & $70+$ & $1: 0.47$ & $1: 0.93$ \\
\hline \multirow[t]{2}{*}{ India } & $50+$ & $1: 0.96$ & $1: 0.91$ \\
\hline & $70+$ & $1: 1 \cdot 04$ & $1: 1 \cdot 05$ \\
\hline \multicolumn{4}{|l|}{ Caucasians } \\
\hline \multirow[t]{2}{*}{ South Africa } & $50+$ & $1: 1 \cdot 08$ & $1: 1 \cdot 17$ \\
\hline & $70+$ & $1: 1 \cdot 08$ & $1: 1 \cdot 56$ \\
\hline \multirow[t]{2}{*}{ U.S.A.* } & $50+$ & $1: 1 \cdot 04$ & $1: 1 \cdot 19$ \\
\hline & $70+$ & $1: 1 \cdot 16$ & $1: 1.45$ \\
\hline \multirow[t]{2}{*}{ England and Wales } & $50+$ & $1: 1 \cdot 29$ & $1: 1 \cdot 29$ \\
\hline & $70+$ & $1: 1 \cdot 52$ & $1: 1 \cdot 90$ \\
\hline
\end{tabular}

* Data on U.S.A. populations relate to the years 1950 and 1969. 
sex ratios, in persons of 50 or more years, excluding Indians, females predominate. In the older segments, those of 70 and more years, there was an increase in female advantage, which additionally increased considerably during the period under consideration. Among Caucasian populations, the female predominance at 70 or more years in England and Wales, reflected in the male : female ratio, $1: 1.90$, is much greater than that in the United States, $1: 1 \cdot 45$. The ratios for both populations stand in gross contrast to the ratio in westernized Indians in South Africa, $1: 0.93$. It is noteworthy that it has been reported that in rural India, females have a much higher death rate than males in every age group except at 65 years and over (Gordon, Singh and Wyon, 1961). It is remarkable that according to the respective male : female ratios, the mortality situation of Indian females in South Africa is more adverse than that of their compatriots in India.

\section{Discussion}

For depicting the general ageing pictures of populations at 50 years and beyond, the survival index, although admittedly crude, is regarded as adequate for the purpose in mind. Furthermore, although data on the populations in the different countries differ in degree of accuracy, it requires large errors in assessment to appreciably alter the figures given in Tables 2 and 3.

Understandably, the various populations aged 50 years and over are not wholly comparable, since, as already indicated, there are differences in the respective wastages of life up to that age. Attrition was, and at present still is, greater in the South African Negro and Indian, compared with the Caucasian groups. It is doubted, however, whether the magnitude of the differences in wastage has a significant bearing on differences in age structure after middle age, or on their explanation.

It is remarkable that the survival percentage of middle-aged and elderly South African Negroes was the highest of the populations studied, although, as noted in the introduction, even in total populations, very aged persons are known to be proportionally more common among Negroes than among South African Caucasians (Population Census, 1958 and 1963). It is highly relevant that among South African Negroes, coronary heart disease remains virtually absent (Walker, 1973), and total cancer incidence (age specific) is still much lower than that prevailing with the local Caucasian population (Oettlè, 1964; Harrington, personal communication). It is particularly apposite that in a recent investigation in Uganda on old Africans, it was stated that they die, not from degenerative diseases, but from 'diseases of childhood, such as infections, acute tuberculosis, neglect and malnutrition' (Drury, 1972).

The situation prevailing with the Indian populations, especially that in South Africa, is highly alarming. In India, where the huge bulk of the population are rural dwellers, the majority of deaths in adults, and also, of course, in the young, are due to infections (Rau and Rao, 1959; Gordon et al., 1961; Park and Prasad, 1963). In strong contrast, among South African Indians, deaths for adults are due mainly to coronary heart disease, strokes, and diabetes (Walker, 1968, 1973). Since the survival figure for South African Indians is not better than that of Indians in India, it is inferred that at middle age and thereafter, the degenerative diseases associated with westernization are just as noxious and lethal as the infections which are linked with the adverse environmental conditions usual to primitive and developing populations. That no improvement in longevity after middle age has occurred is very disappointing as the socio-economic circumstances, also the medical services, of South African Indians are far superior to those of Indian populations in India. For example, in Lenasia, Johannesburg, where about 40,000 Indians live, our investigations have revealed that about one half of families have servants full-time, and a quarter, part-time; furthermore, about one half possess motor cars. Moreover, in Lenasia, preliminary studies of 250 families in (1) best circumstances, and (2) poor circumstances, have revealed survival percentages (as described in this contribution) of 17.6 and $19 \cdot 1$, respectively, suggesting that the more affluent the group, the greater is their jeopardy. There is also evidence suggestive that Indians in South Africa over-react to noxious influences and to challenges to the metabolism, the response at least in part being probably of genetic origin. For example, biochemically, it has been found that insulinaemia following a glucose dose is far higher in Indians, even in children of 10-12 years, than in Negroes and Caucasians of the same age (Keller, Schatz and Jackson, 1972; Walker, Bernstein and du Plessis, 1972).

On making a comparison between South African Negroes and United States Negroes, and between Indians in India and in South Africa, it is clear that when considering the middle-aged and over, their survival capacity has not been improved, indeed it is perhaps being diminished, by sophistication of diet and manner of life.

Burch (1972) has averred that 'people live no longer anymore'. He recently pointed out that in the United States, expectations of life at birth reached plateaux 20 years ago; the figures for Whites and Negroes are about 71 and 64 years, respectively, and for total males and females, about 68 and 73 
years. In western populations, within the last 300 years, expectation of life at 60 years has increased by only 3-5 years, and at 80 years, possibly by a year (Wiesler, 1962; Walker, 1969). Moreover, there is evidence that in some populations already a decline in life expectancy at middle age is occurring; this has been reported to prevail since 1940 in the Jewish population of the United States (Fauman and Mayer, 1969). All this is happening, as Burch emphasized, in spite of billions of money spent on research, and in spite of the huge increases in health services 'input' in western populations, as has occurred, for example, in the British National Health Serivces (Cochrane, 1972).

\section{Acknowledgments}

The investigations described form part of a programme of research aimed at increasing knowledge on diet, metabolism, and patterns of health and disease in the elderly in South African ethnic groups. The research is being supported by the International Sugar Research Foundation and the National Cancer Association of South Africa.

Miss Munira Wadvalla gave considerable help in the acquiring of the requisite data. Dr G. T. Nurse, of the SeroGenetics Department of this Institute gave valuable advice.

\section{References}

Burch, G.E. (1972) People live no longer anymore. American Heart Journal, 83, 285.

Bulletin of Statistics. Quarter Ended March 1971. Department of Statistics, Vol. 5, No. 1. Government Printer, Pretoria.

Cochrane, A.L. (1972) Effectiveness and Efficiency. The Nuffield Provincial Hospitals Trust, London.

DemograPhic YeARBOOK, 1970. (1971) United Nations Publications, New York.

DRURY, R.A.B. (1972) The mortality of elderly Ugandan Africans. Tropical and Geographical Medicine, 24, 385.

Gordon, J.E., Singh, S. \& Wyon, J.J. (1961) Field study of deaths and causes of deaths in rural populations of the Punjab, India. American Journal of Medical Science, 214, 359. Fauman, S.J. \& Mayer, A.J. (1969) Jewish mortality in the $\frac{\nwarrow}{\mathbb{Q}}$
U.S. Human Biology, 41, 416.

Keller, P., Schatz, L. \& JACKson, W.P.U. (1972) Immuno-c reactive insulin in various South African population groups. South African Medical Journal, 46, 152.

New Information Please Almanack. Atlas and YearBOOK (1972) Ed. by Dan Golenpaul, New York.

Oettle, A.G. (1964). Cancer in Africa, especially in regions South of the Sahara. Journal of the National Cancer $\frac{\bar{\sigma}}{\sqrt{2}}$ Institute, 33, 383.

Park, J.E. \& Prasad, B.G. (1963) Health survey of Natwara village in Madhya Pradesh. Indian Journal of Medical os Research, 17, 300.

Population Census, 1951 (1958) Ages-All Races. Vol. V. $\vec{\circ}$ Government Printer, Pretoria.

Population Census, 1960 (1963) Miscellaneous Characteristics according to Age. All Races. Vol. 9. Government $\frac{\partial}{\partial}$ Printer, Pretoria.

RAU, S.S. \& RAO, S.V. (1959) Pilot Study on Local Health Services in Ramanagaram, Mysore, India. WHO/PHA/30. ir Expert Committee on Public Health Administration. World Health Organization, Geneva.

Registrar General's Statistical Review of England AND Wales for the Year 1951 (1953) Part II. Tables, N Civil. Her Majesty's Stationery Office, London.

Registrar General's Statistical Review of England AND WALES for THE YeAR 1970 (1972) Part II. Tables, Population. Her Majesty's Stationery Office, London.

Statistical Abstract of The United States (1960) 81st annual edn. U.S. Department of Commerce, Bureau of the Census, New York.

Statistical News Release (1972) Census of 6th May, 197Q. Department of Statistics. Government Printer, Pretoria.

WALKER, A.R.P. (1968) Coronary heart disease and futuke $\perp$ expectation of life. Circulation, 37, 126.

WALKER, A.R.P. (1969) What can be done to retard ageing and to increase expectation of life? Annals of Life Insurance Medicine, 4, 176.

Walker, A.R.P., Bernstein, R.E. \& DU Pl.essis, I. (1972) Hyperinsulinaemia from glucose dose in South African 응 Indian children. South African Medical Journal, 46, 1916. @

WALKER, A.R.P. (1973) Studies bearing on coronary heart $\overrightarrow{\vec{B}}$ disease in South African populations. South African $\frac{0}{3}$ Medical Journal, 47, 85.

WIESLER, H. (1962) The investigation of mortality. Annals of Life Insurance Medicine, $1,3$. 